\title{
Bovine Somatotropin Increases Hepatic Phosphoenolpyruvate Carboxykinase mRNA in Lactating Dairy Cows ${ }^{*}{ }^{\dagger}$
}

\author{
J. C. Velezł and S. S. Donkin \\ Department of Animal Sciences, \\ Purdue University, West Lafayette, IN 47907
}

\begin{abstract}
Somatotropin (ST) increases milk production and through coordinated changes in hepatic glucose synthesis and amino acid metabolism in dairy cows. The objective of this study was to determine the effects of ST on hepatic mRNA expression for phosphoenolpyruvate carboxykinase (PEPCK) and pyruvate carboxylase (PC), enzymes that are critical to the synthesis of glucose in liver and hepatic mRNA expression for carbamylphosphate synthetase I (CPS-I), argininosuccinate synthetase (AS), and ornithine transcarbamylase (OTC), critical enzymes of the urea cycle. Eighteen cows were randomly allocated to 2 treatment groups and received either recombinant bovine ST (Posilac; Monsanto, St. Louis, MO) or saline injections at 14-d intervals during a 42-d period. Expression of mRNA was determined using Northern blot analysis. Nuclei, isolated from liver biopsy samples, were used to determine effects of ST on transcription rate of PEPCK. Milk production was increased with ST (37.3 vs. $35.1 \pm 0.6 \mathrm{~kg} /$ d). Plasma NEFA was increased with ST (299 vs. 156 $\pm 34 \mu M)$. There were no differences in the expression of CPS-I, AS, and OTC mRNA with ST. Expression of PEPCK and IGF-I mRNA were increased with ST but PC mRNA was unchanged. The data indicate increased PEPCK mRNA in cows given ST and indicates a greater capacity for gluconeogenesis from gluconeogenic precursors that form oxaloacetate. The effects of ST to elevate PEPCK mRNA expression require chronic administration and involve increased transcription of the PEPCK gene.
\end{abstract}

(Key words: somatotropin, PEPCK, liver, gene)

Received May 22, 2003.

Accepted October 1, 2003.

Corresponding author: S. S. Donkin; e-mail: sdonkin@purdue.edu.

* Supported in part by funds from the Indiana Agricultural Research Programs as a contribution to North Central Regional project NC-1009 and USDA National Research Initiative Competitive Grant 2001-35206-11265 (to SSD).

$\dagger$ Mention of trade name does not constitute endorsement by Purdue University.

$\ddagger$ Current Address: Abbott Laboratories, Abbott Park, IL.
Abbreviation key: AS = argininosuccinate synthetase, $\mathbf{C P S}-\mathbf{I}$ = carbamylphosphate synthetase I, GHR = growth hormone receptor, OTC = ornithine transcarbamylase, $\mathbf{P C}=$ pyruvate carboxylase, $\mathbf{P E P C K}=$ phosphoenolpyruvate carboxykinase, $\mathbf{P U N}=$ plasma urea nitrogen, $\mathbf{S T}$ = somatotropin.

\section{INTRODUCTION}

Administration of bovine somatotropin (ST) increases milk production in dairy cows through a series of coordinated metabolic adaptations to repartition nutrients towards lactation (Bauman, 1992). One of these changes involves increased glucose turnover (Bauman, 1992), a portion of which represents increased gluconeogenesis in liver (Knapp et al., 1992).

Primary targets for somatotropin action are bone, liver, adipose tissue, and muscle (Bauman, 1992). Somatotropin acts through its membrane-bound receptor to activate JAK2, a member of the Janus family of tyrosine kinases (Carter-Su et al., 1996). Active JAK2 stimulates signal transducers and activators of transcription proteins to modify gene expression and cell metabolism (Herrington et al., 2000). Despite the commercial use of bovine ST, there is a lack of information on the molecular mechanisms that accompany increased hepatic glucose output in response to ST in dairy cows.

Changes in plasma glucose entry rate that accompany ST administration (Bauman et al., 1988) may be a secondary response to increased feed intake that often accompanies ST use in dairy cows (Bauman et al., 1989) as the rate of gluconeogenesis is responsive to hormone and substrate concentrations (Donkin and Armentano, 1995). Alternatively, changes in gluconeogenesis with ST may be the result of adaptative decreases in metabolite oxidation and increased nutrient use for gluconeogenesis by liver (Knapp et al., 1992). A portion of the latter response may involve changes in activity of key gluconeogenic enzymes.

Pyruvate carboxylase (PC) and phosphoenolpyruvate carboxykinase (PEPCK) are 2 key gluconeogenic enzymes. Both PC and PEPCK are expressed in liver and 
adipose tissue, which are primary target tissues for ST. Conversion of oxaloacetate to phosphoenolpyruvate (PEP), catalyzed by PEPCK, is considered to be the committed step in the gluconeogenic pathway in some species (Pilkis and Granner et al., 1992). Pyruvate carboxylase catalyzes the ATP-dependent carboxylation of pyruvate to form oxaloacetate and may be critical in determining use of lactate, pyruvate, and amino acids for glucose formation.

Administration of ST is associated with an increased efficiency of nutrient utilization, which is reflected through decreased plasma urea nitrogen (PUN) concentrations and urinary N excretion (Eisemann, 1989; Boisclair, 1994). Decreased expression of urea cycle enzymes carbamylphosphate synthetase I (CPS-I), argininosuccinate synthetase (AS), and arginino succinate lyase but not ornithine transcarbamylase (OTC) is observed when ST is administered to rats (Grofte et al., 1998). Previous work shows that ST improves rate of muscle accretion in growing pigs (Chung et al., 1985). These changes are coupled to IGF-I and act to reduce hepatic degradation of amino acids (Grofte et al., 1998). The decreased expression of urea cycle enzymes and reduced urea $\mathrm{N}$ excretion in response to ST may reflect channeling of amino acids away from catabolism and into body protein.

The present study was conducted to test the hypothesis that ST acts to enhance milk production through alterations in expression of mRNA encoding key enzymes for critical metabolic pathways in liver. The objective of the present study was to determine the effects of ST on hepatic mRNA expression for PEPCK and PC, 2 key enzymes involved in gluconeogenesis and mRNA expression for CPS-I, AS, and OTC, key enzymes of the urea cycle.

\section{MATERIALS AND METHODS}

\section{Animals, Management, and Sampling}

Eighteen multiparous Holstein cows selected from the Purdue University Dairy Research and Education Center herd were stratified by DIM and assigned to either ST or control treatments. Cows averaged $34.6 \pm$ $0.6 \mathrm{~kg} / \mathrm{DIM}$ and were $116 \pm 6 \mathrm{DIM}$ at the beginning of the trial. Cows were housed in individual tie stalls, had free access to water, were milked twice daily at 0800 and $2000 \mathrm{~h}$, and fed a diet to meet or exceed nutrient requirements (NRC, 2001) (Table 1). Cows had ad libitum access to feed supplied in amounts to ensure 10\% feed refusals. Feed intake was measured daily by difference of feed offered and refused (Table 2). Animals were handled according to the recommendations and procedures approved by the Purdue Animal Care and Use Committee.
Table 1. Diet ingredients and nutrient composition.

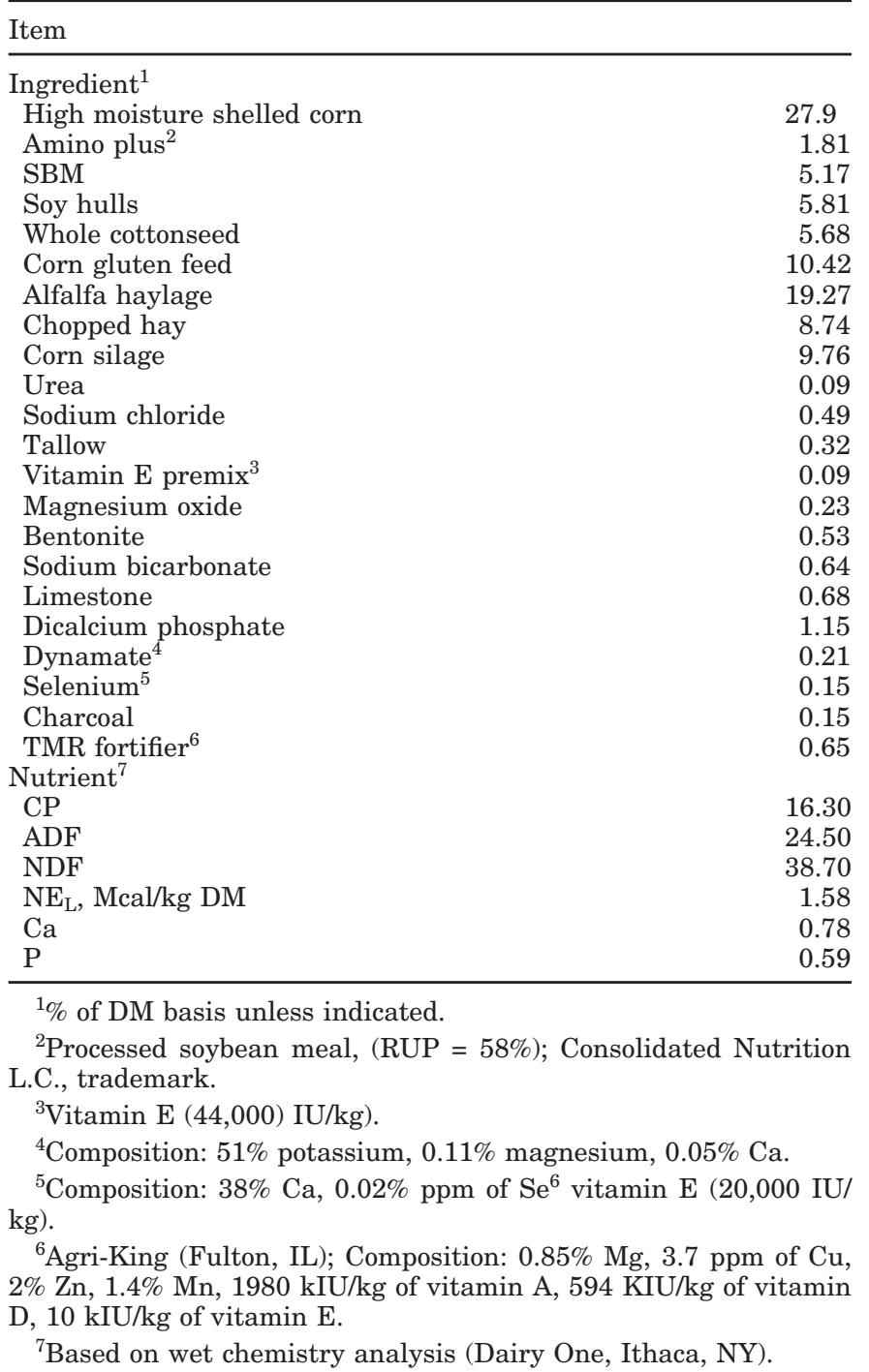

Cows assigned to the ST group $(\mathrm{n}=9)$ were injected with Posilac (Monsanto Co., St. Louis, MO), a commercially available recombinant bST designed to deliver $500 \mathrm{mg}$ of recombinant bST over a 14-d period. Cows were injected with ST on d 1, 14, and 28. Control cows $(\mathrm{n}=9)$ were injected with $1.4 \mathrm{~mL}$ of physiological saline $(0.9 \% \mathrm{NaCl})$ on the same days.

Samples of individual ration ingredients were collected weekly throughout the trial, dried in a convection oven at $55^{\circ} \mathrm{C}$, and used for adjustments to TMR. Samples of the ration were collected weekly and used to form a composite sample that was analyzed by a commercial laboratory (Dairy One, Ithaca, NY) by wet chemistry (Table 1).

Milk yield was recorded electronically at each milking (HerdMaster Galaxy Management System, Alfa-Laval Agri Inc., St. Louis, MO), and milk samples were ob- 
Table 2. Effects of somatotropin (ST) on feed intake, milk production, and milk composition. Cows were injected with recombinant ST as Posilac (Monsanto, St. Louis, MO) on 3 occasions at 14-d intervals over a 42-d period. Data are LS means and standard errors means of data for main effects (injection cycles 1, 2, and 3 combined).

\begin{tabular}{|c|c|c|c|c|c|}
\hline & \multicolumn{2}{|c|}{ ST } & \multicolumn{2}{|c|}{ Control } & \multirow[b]{2}{*}{$P$ value ${ }^{1}$} \\
\hline & Mean & SE & Mean & $\mathrm{SE}$ & \\
\hline Feed intake, $\mathrm{kg} / \mathrm{d}^{\mathrm{a}, \mathrm{b}}$ & 27.4 & 0.5 & 26.1 & 0.5 & $<0.05$ \\
\hline Milk, $\mathrm{kg} / \mathrm{d}^{\mathrm{a}, \mathrm{b}}$ & 38.6 & 1.4 & 33.8 & 1.4 & $<0.05$ \\
\hline $\mathrm{FCM}, \mathrm{kg} / \mathrm{d}^{\mathrm{a}, \mathrm{b}}$ & 38.1 & 1.0 & 34.4 & 1.0 & $<0.05$ \\
\hline Milk fat, $\mathrm{kg} / \mathrm{d}^{\mathrm{a} \cdot \mathrm{b}}$ & 1.55 & 0.05 & 1.38 & 0.05 & $<0.05$ \\
\hline Milk protein, $\mathrm{kg} / \mathrm{d}^{\mathrm{a} . \mathrm{b}}$ & 1.17 & 0.02 & 1.00 & 0.02 & $<0.05$ \\
\hline Milk lactose, $\mathrm{kg} / \mathrm{d}$ & 1.84 & 0.07 & 1.63 & 0.07 & 0.06 \\
\hline Milk SNF, kg/d $\mathrm{d}^{\mathrm{a}, \mathrm{b}}$ & 3.35 & 0.03 & 2.92 & 0.10 & $<0.05$ \\
\hline Milk MUN, mg/dL ${ }^{b}$ & 15.67 & 0.42 & 15.53 & 0.44 & 0.82 \\
\hline Milk SCC & 291 & 80 & 141 & 84 & 0.21 \\
\hline Milk fat, $\%^{\mathrm{b}}$ & 4.02 & 0.15 & 4.09 & 0.15 & 0.72 \\
\hline Milk protein, $\%^{\mathrm{b}}$ & 3.03 & 0.06 & 2.98 & 0.06 & 0.55 \\
\hline Milk lactose, $\%^{\mathrm{b}, \mathrm{c}}$ & 4.76 & 0.04 & 4.79 & 0.05 & 0.69 \\
\hline Milk solids, $\%^{\mathrm{b}}$ & 8.67 & 0.08 & 8.64 & 0.08 & 0.78 \\
\hline
\end{tabular}

aTreatment effect $(P<0.05)$.

${ }^{\mathrm{b}}$ Time effect $(P<0.05)$.

'Treatment $\times$ time effect $(P<0.05)$.

${ }^{1} P$ value associated with treatment effect.

tained for 2 consecutive milkings during each week of the experiment and analyzed for milk fat, milk protein, MUN, and SCC at the DHIA Laboratory (East Lansing, MI).

Liver biopsy samples were obtained by blind percutaneous needle biopsy on $d 21$ and 35 of the trial, which corresponded to $7 \mathrm{~d}$ after the second and third ST injections. Liver biopsy samples were rinsed in saline and immediately transferred into a 50-mL conical tube containing $10 \mathrm{~mL}$ of guanidinium thiocyanate solution (4 $M$ guanidinium thiocyanate, $25 \mathrm{~m} M$ sodium citrate $(\mathrm{pH}$ 7.4), $0.5 \%$ sarcosyl, and $0.1 M$ beta-mercaptoethanol), frozen in liquid nitrogen and stored at $-80^{\circ} \mathrm{C}$ pending RNA extraction.

Blood samples and BW were obtained when liver biopsies were performed. Two blood samples were collected from a coccygeal blood vessel into Vacutainers (Becton Dickinson, Franklin Lakes, NJ). One sample was collected into a $15-\mathrm{mL}$ tube containing a combination of potassium oxalate and sodium fluoride, the other tube was treated with heparin. Plasma was separated by centrifugation at $550 \times \mathrm{g}$ for $15 \mathrm{~min}$ and was frozen at $-20^{\circ} \mathrm{C}$ pending analysis.

\section{Plasma Analysis}

Assays for glucose (Carroll et al., 1970) and NEFA (Johnson and Peters, 1993) were conducted in a 96-well microplate format and read on a Packard SpectraCount plate reader (Packard Instrument Co., Meriden, CT) using commercial kits (Glucose \# 115-A; Sigma Chemical Co., St. Louis, MO; NEFA-C kit, Wako Fine Chemi- cals Industries USA, Inc., Dallas, TX) and plasma samples collected in tubes containing potassium oxalate and sodium fluoride. Plasma urea nitrogen concentrations were determined using a colorimetric method (Crocker, 1967; Sigma BUN kit 535, Sigma Diagnostics). Plasma glucagon and insulin were determined using radioimmunoassay kits and the human standards supplied (Diagnostic Products Corporation, Los Angeles, CA). Variation within assay for insulin averaged $5.7 \%$, and variation between assays was $5.1 \%$. Variation within assay for glucagon averaged $4.9 \%$, and variation between assays was $2.4 \%$.

\section{cDNA Probes}

Plasmids bPC1000, containing a 1051-bp fragment of bovine PC cDNA and bPEPCK- 700, containing 1150bp fragment for bovine PEPCK cDNA, were cloned in our laboratory (Agca et al., 2002). Plasmid bGHR1A containing a 312-bp fragment of the bovine growth hormone receptor cDNA and pbIGF-I containing a 314-bp fragment of the bovine insulin-like growth factor-I were gifts from Matt Lucy (Department of Animal Sciences, Missouri State University, St. Louis). The cDNA insert for pGHR1A recognizes 312- and 121-bp nucleotide fragments corresponding to the GHR1A and GHR1B variants of the bovine growth hormone receptor, respectively. Plasmid pAS4, containing a 1.5-kb fragment of the human argininosuccinate synthetase cDNA, plasmid pOTC containing a 1.2-kb fragment of the human OTC cDNA, and plasmid pCPS-I containing a $5.3-\mathrm{kb}$ fragment of rat CPS-I were purchased from American 
Type Culture Collection (ATCC, Rockville, MD). The plasmid pDF8 containing a 1.06-kb fragment corresponding to the central region of the rat $18 \mathrm{~S}$ rRNA gene was provided by Richard Torzynski (Cytoclonal Pharmaceutics Inc., Dallas, TX).

The cDNA inserts were excised from plasmids by restriction enzyme digestion, followed by separation in low-melting temperature agarose gel and purification using the Wizard DNA purification system (Promega, Madison, WI). Radiolabeled cDNA probes were generated using ${ }^{32} \mathrm{P}[\mathrm{dCTP}]$ and the Ready-to-go DNA labeling kit (Pharmacia, Piscataway, NY) by oligonucleotide priming. The specific activity of cDNA probes was approximately $10^{9} \mathrm{cpm} / \mu \mathrm{g}$ of DNA.

\section{Northern Blot Analysis}

Total RNA was extracted from liver biopsy samples (Chomczynski and Sacchi, 1987), and a 20- $\mathrm{g}$ g aliquot was separated by electrophoresis through a $1 \%$ agarose gel (Tsang et al., 1993) and transferred to Genescreen membrane (NEN Life Science Products, Boston, MA) by capillary action. The RNA was cross-linked using UV light, and the membrane was baked at $80^{\circ} \mathrm{C}$ for $2 \mathrm{~h}$ to remove any residual formaldehyde as per the manufacturer's instructions. Membranes were prehybridized for $12 \mathrm{~h}$ in $50 \%$ deionized formamide, $5 \times \mathrm{SSPE}$ $\left(0.75 M \mathrm{NaCl}, 0.05 M \mathrm{NaH}_{2} \mathrm{PO}_{4} \mathrm{H}_{2} \mathrm{O}\right.$, and $5 \mathrm{~m} M$ EDTA), $5 \times$ Denhardt's $(0.1 \%$ ficoll, $0.1 \%$ polyvinylpyrrolidone, and $0.1 \%$ bovine serum albumin), $10 \%$ dextran sulfate, and $200 \mu \mathrm{g} / \mathrm{mL}$ of denatured herring sperm DNA at $42^{\circ} \mathrm{C}$ for 6 to $18 \mathrm{~h}$. Hybridization was performed in the same solution with the addition of ${ }^{32} \mathrm{P}$-labeled cDNA (2 $\times 10^{6} \mathrm{cpm} / \mathrm{mL}$ ) for $16 \mathrm{~h}$ at $42^{\circ} \mathrm{C}$. Following hybridization the membranes were washed twice in $2 \times \operatorname{SSC}(0.3 \mathrm{M}$ $\mathrm{NaCl}, 0.03 M$ sodium citrate, $\mathrm{pH} 7.0$ ) for $5 \mathrm{~min}$ at room temperature, twice in $2 \times \mathrm{SSC}, 1 \% \mathrm{SDS}$ at $65^{\circ} \mathrm{C}$ for 30 min, and twice in $0.1 \times \mathrm{SSC}(0.015 M \mathrm{NaCl}, 0.0015 M$ sodium citrate, $\mathrm{pH} 7.0$ ) for $30 \mathrm{~min}$ at room temperature.

Membranes were exposed to Kodak X-Omat AR film and mRNA quantified using Kodak Digital Science 1D Image Analysis software (Eastman Kodak Co., Rochester, NY). Multiple sets of combs within a gel were necessary to accommodate all samples for the experiment. To account for possible differences between sets of samples, a pooled sample $(20 \mu \mathrm{g})$ of bovine liver RNA was added to outside lanes within each set of samples and used to adjust for variation in transfer of RNA, and hybridization conditions. Variations in sample loading were adjusted using the abundance of $18 \mathrm{~S}$ rRNA within each sample.

\section{Ribonuclease Protection Assay}

Bovine growth hormone receptor was analyzed by ribonuclease protection assay using the plasmid
bGHR1A. Linearized pGHR1A was incubated with T7 primers in the presence of ${ }^{32} \mathrm{P}[\mathrm{UTP}]$ and NTP to generate a ${ }^{32} \mathrm{P}$-labeled bGHR antisense RNA probe. Individual RNA samples were incubated with GHR1A riboprobe containing $20 \mu \mathrm{g}$ of sense sample RNA. Unhybridized RNA was digested using a mixture of RNases $\mathrm{T}$ and $\mathrm{A}$ at $37^{\circ} \mathrm{C}$ for $30 \mathrm{~min}$. Protected RNA fragments were size separated by electrophoresis through a $5 \mathrm{M}$ urea, 5\% polyacrylamide gel. A set of ${ }^{32} \mathrm{P}$-labeled RNA molecular size standards were generated from the Century RNA marker template (Ambion, Austin, TX) and were electrophoresed in lanes flanking the RNA samples. The protected RNA fragments and markers were visualized by exposure of the dried polyacrylamide gel to X-ray film (Fuji Medical Systems U.S.A., Inc., Stamford, CT.) for $24 \mathrm{~h}$. The protected RNA fragments for bGHR1A and $18 \mathrm{~S}$ were quantified using the Kodak Digital Science 1D Image Analysis software. The abundance of GHR was normalized to the abundance of $18 \mathrm{~S}$ for each sample.

\section{Nuclei Isolation and Run-On Transcription Assay}

Liver biopsy samples (approximately $0.5 \mathrm{~g}$ ) obtained following the third ST injection were homogenized using $10 \mathrm{~mL}$ of buffer containing $60 \mathrm{~m} M \mathrm{KCl}, 15 \mathrm{~m} M$ $\mathrm{NaCl}, 0.15 \mathrm{~m} M$ spermine, $0.5 \mathrm{~m} M$ spermidine, $14 \mathrm{~m} M$ beta-mercaptoethanol, $0.5 \mathrm{~m} M$ EGTA, $2 \mathrm{~m} M$ EDTA, 15 $\mathrm{m} M$ HEPES ( $\mathrm{pH}$; 7.5; Buffer A), and $0.3 M$ sucrose. The homogenate was filtered through cheesecloth and layered on a 10-mL cushion of buffer A containing $30 \%$ sucrose. Samples were centrifuged for $10 \mathrm{~min}$ at $125,000 \times g$ at $4^{\circ} \mathrm{C}$. The pellet was resuspended in 3.5 $\mathrm{mL}$ of a buffer containing $2 M$ sucrose in $60 \mathrm{mM} \mathrm{KCl}$, $15 \mathrm{~m} M \mathrm{NaCl}, 0.15 \mathrm{~m} M$ spermine, $0.5 \mathrm{~m} M$ spermidine, $14 \mathrm{~m} M$ beta-mercaptoethanol, $0.1 \mathrm{~m} M$ EGTA, $0.1 \mathrm{~m} M$ EDTA, $15 \mathrm{~m} M$ HEPES (pH 7.5; Buffer B), and was then layered over a buffer containing $60 \mathrm{mM} \mathrm{KCl,} 15 \mathrm{mM}$ $\mathrm{NaCl}, 0.15 \mathrm{~m} M$ spermine, $0.5 \mathrm{~m} M$ spermidine, $14 \mathrm{~m} M$ beta-mercaptoethanol, $0.1 \mathrm{~m} M$ EGTA, $0.1 \mathrm{~m} M$ EDTA, and $2 M$ sucrose and sedimented at $195 \times g$ at $4^{\circ} \mathrm{C}$ for $1 \mathrm{~h}$. The nuclear pellets were resuspended in $100 \mu \mathrm{L}$ of nuclei storage buffer (20 mM Tris-HCl, $\mathrm{pH} 7.9), 75 \mathrm{mM}$ $\mathrm{NaCl}, 0.5 \mathrm{~m} M$ EDTA, $0.85 \mathrm{~m} M$ dithiothreitol, $0.125 \mathrm{mM}$ phenylmethylsulfonyl fluoride, $50 \%$ glycerol (vol/vol). Nuclei were frozen in liquid nitrogen and stored at $-80^{\circ} \mathrm{C}$ pending RNA extraction for in vitro elongation of nascent RNA chains.

Nuclei were thawed on ice, and $100 \mu \mathrm{L}$ was used for in vitro mRNA elongation reactions carried out according to Schibler et al. (1983). The reaction mixture contained $100 \mathrm{~m} M$ Tris- $\mathrm{HCl}$ (pH 7.9), $50 \mathrm{~m} M$ NaCl, 0.4 $\mathrm{m} M$ EDTA, $0.1 \mathrm{~m} M$ phenylmethylsulfonyl fluoride, 1.2 
$\mathrm{m} M$ dithiothretol, $4 \mathrm{mM} \mathrm{MgCl}, 2$ to $5 \mu M \alpha{ }^{3}{ }^{32} \mathrm{P}$-UTP $3000 \mathrm{Ci} / \mathrm{mmol}, 1 \mathrm{~m} M$ each of GTP, ATP, and CTP, $29 \%$ glycerol, $10 \mathrm{~m} M$ creatine phosphate, $130 \mathrm{U} / \mathrm{mL}$ of ribonuclease inhibitor. In vitro mRNA synthesis reaction was performed by the addition of approximately $4 \times 10^{7}$ nuclei $/ \mathrm{mL}$, and the elongation reactions were incubated for $30 \mathrm{~min}$ at $26^{\circ} \mathrm{C}$. Immediately following elongation, $1 \mu \mathrm{L}$ of $20000 \mathrm{U}$ of RNase-free DNase/mL was added to the samples and incubated at room temperature for 5 min. Yeast tRNA ( $5 \mu \mathrm{L}$ of $10 \mathrm{mg} / \mathrm{mL}$ solution) was added and the newly transcribed ${ }^{32} \mathrm{P}$-labeled RNA was isolated using the method of Chomcyznski and Sacchi (1987) adapted for nuclear RNA by Fei and Drake (1993).

Linearized plasmids for bPEPCK-700, pGEM3Z (Promega, Madison, WI), and pDF8 were used as target DNA for run-on transcription assay. The linearized DNA was denatured with $\mathrm{NaOH}(1 M)$, and spotted onto Genescreen membrane using a slotblot manifold and then immobilized by UV cross-linking and baking at $80^{\circ} \mathrm{C}$ for $2 \mathrm{~h}$. Membranes were prehybridized in 20 $\mathrm{mL}$ liquid scintillation vials containing $5 \mathrm{~mL}$ and $50 \%$ deionized formamide, $5 \times$ SSPE, $5 \times$ Denhardt's, $10 \%$ dextran sulfate and $200 \mathrm{~g}$ of denatured salmon sperm $\mathrm{DNA} / \mathrm{mL}$ at $42^{\circ} \mathrm{C}$. The addition of ${ }^{32} \mathrm{P}$-labeled elongation product was equalized across hybridization vials $(1 \times$ $\left.10^{6}\right)$. Hybridization time was $16 \mathrm{~h}$ at $42^{\circ} \mathrm{C}$. Membranes were washed twice in $2 \times \mathrm{SSC}(0.3 \mathrm{M} \mathrm{NaCl}, 0.03 M$ sodium citrate, $\mathrm{pH}$ 7.0) for $5 \mathrm{~min}$ at room temperature, twice in $2 \times, 1 \%$ SDS at $55^{\circ} \mathrm{C}$ for $30 \mathrm{~min}$, and twice in $0.1 \times \mathrm{SSC}(0.015 M \mathrm{NaCl}, 0.0015 M$ sodium citrate, $\mathrm{pH}$ 7.0) for $30 \mathrm{~min}$ at room temperature. Results were visualized on X-ray film and quantified by densitometric scanning. Binding of labeled mRNA to target DNA was normalized using the binding of labeled RNA to the cDNA for rat $18 \mathrm{~S}$ rRNA.

\section{Statistical Analysis}

Data were analyzed as a completely randomized design. The model accounted for the effects of treatment, cow within treatment, injection cycle (d 1 to 14,15 to 28 , and 29 to 42 ), and treatment $\times$ injection cycle. Data were analyzed by the PROC MIXED procedure of SAS. Cow within treatment was specified as the error term for random and repeated tests, and treatment $\times$ injection cycle effects were determined using cow $\times$ treatment $\times$ injection cycle as the error term. The covariance structure was determined for anti-dependence, simple, unstructured, and autoregressive models. The model that yielded the minimum range of values for Akaike Information Criterion and Bayesian Information Criterion for each variable was used for data analysis. The data are presented as least square means and standard errors. Comparisons between control and ST within injection cycle are considered different when $P<0.05$, a trend in the data is defined as $0.05 \leq \mathrm{I} \leq 0.10$.

\section{RESULTS AND DISCUSSION}

\section{DMI and Milk Production}

Milk yield increased $(P<0.05)$ in response to ST (Table 2) as well as milk fat, protein, and lactose yield. There were no changes in the percentages of fat, protein, or lactose in milk. Milk yield response to ST has been observed for all dairy breeds and in animals of different parity and genetic potential (Bauman and Vernon, 1993; Hartnell, 1995; NRC, 2001). The response to exogenous ST, although observed in the present experiment, was modest compared with the 10 to $15 \%$ increases in milk yield reported elsewhere (Bauman and Eppard, 1985; Bauman et al., 1989; Stanisiewski et al., 1992).

Dry matter intake increased 5\% for cows receiving ST. Short-term administration of exogenous ST in other studies resulted in either decreased ad libitum intake, a $16 \%$ increase in feed intake (Peel et al., 1983), or a lack of difference in feed intake (Eppard et al., 1985; McDowell et al., 1987). Long-term (188 d) daily injections of recombinant somatotropin resulted in net energy intake that is similar for the first 5 wk despite a trend for increased feed after $10 \mathrm{wk}$ of treatment (Bauman and Eppard, 1985). Other studies report increased feed intake by wk 8 when cows are given daily ST injections (Peel et al., 1983). The $14 \%$ increase in milk production in the present study is supported by a $5 \%$ increase in feed intake. Cows weighed $599 \pm 9 \mathrm{~kg}$ at the beginning of the experiment and did not differ between groups. The average BW loss combined across the 3 injection cycles did not differ $(P>0.05)$ for both groups ( 4 and $2 \pm 3 \mathrm{~kg}$ for control and bST). The response in milk production and feed intake in the present experiment provides a basis for further examining the physiological mechanisms that support increased milk production with ST administration.

\section{Plasma Metabolites and Hormones}

Previous data indicates a time-dependent response to sustained-release ST on milk production (Bauman et al., 1989), therefore blood and liver sampling was restricted to injection cycle 2 and 3 of the present experiment when the response to bST, if present, would be fully manifested. Plasma concentrations of glucose $(\mathrm{mg} /$ $\mathrm{dL})$ did not differ $(P>0.05)$ (Table 3$)$ for cows given ST and saline. Normal glucose levels for ruminants range between 40 to $60 \mathrm{mg} / \mathrm{dL}$. Administration of ST to lactating dairy cows had no effect on plasma glucose concen- 
Table 3. Effects of somatotropin (ST) on plasma metabolites, insulin, and glucagon. Cows were injected with recombinant ST as Posilac (Monsanto, St. Louis, MO) on d 1, 14, and 28 of the experiment, and blood samples were withdrawn on d 21 and 35. Data are LS means and standard errors for main effects (treatment cycles 2 and 3 combined) unless noted otherwise.

\begin{tabular}{|c|c|c|c|c|c|}
\hline & \multicolumn{2}{|c|}{$\mathrm{ST}$} & \multicolumn{2}{|c|}{ Control } & \multirow[b]{2}{*}{$P$ value } \\
\hline & Mean & $\mathrm{SE}$ & Mean & $\mathrm{SE}$ & \\
\hline Glucose, $\mathrm{mg} / \mathrm{dL}^{\mathrm{b}}$ & 57.8 & 1.0 & 56.9 & 1.0 & 0.57 \\
\hline NEFA $\mu M^{a, b}$ & $299^{*}$ & 34 & 157 & 34 & $<0.05$ \\
\hline PUN, mg/dL ${ }^{b}$ & 18.5 & 0.5 & 18.7 & 0.5 & 0.80 \\
\hline Insulin, $\mathrm{pg} / \mathrm{mL}$ & 281.9 & 36.7 & 233.8 & 36.7 & 0.37 \\
\hline \multicolumn{6}{|l|}{ Glucagon, $\mathrm{pg} / \mathrm{mL}^{\mathrm{c}}$} \\
\hline Cycle 2 & 157.0 & 10.89 & 165.4 & 10.9 & 0.59 \\
\hline Cycle 3 & $174.6^{*}$ & 10.89 & 142.7 & 10.9 & $<0.05$ \\
\hline Overall & 165.8 & 9.52 & 154.0 & 9.5 & 0.39 \\
\hline Insulin:glucagon ${ }^{\mathrm{d}}$ & 1.10 & 0.17 & 0.93 & 0.20 & 0.50 \\
\hline
\end{tabular}

aTreatment effect $(P<0.05)$.

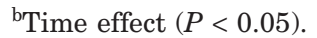

'Treatment $\times$ time effect $(P<0.05)$.

${ }^{\mathrm{d}}$ Molar ratio.

${ }^{1} P$ value associated with treatment effect.

*Mean for ST within a row differs from control $P<0.05$.

trations; however, ST increases irreversible loss of glucose (Bauman et al., 1988). Hepatic rates of gluconeogenesis are increased with ST (Pocius and Herbein, 1986; Knapp et al., 1992). In contrast, growing Holstein steers given ST have increased arterial concentrations of glucose (Boisclair, 1994). Similar increases of plasma glucose are observed for growing pigs chronically injected with porcine ST (Gopinath and Etherton, 1989). Total glucose uptake by mammary tissue increases with ST administration (McDowell et al., 1987), although fractional glucose extraction does not increase in the goat mammary gland with ST (Nielsen et al., 2001). Available data suggests that unchanging levels of blood glucose during ST administration is due to the high demand of glucose for milk synthesis for high milk producing cows (Brier et al., 1991). Therefore increased gluconeogenesis with ST may be offset by increased glucose utilization by mammary tissue.

Plasma NEFA (Table 3$)$ was elevated $(P<0.05)$ for ST-treated cows during the last 2 injection cycles compared with controls. Previous data indicates that plasma NEFA concentration did not change for earlylactation cows given ST but increased for midlactation cows over a 10-d injection cycle (Peel et al., 1983). Elevated serum NEFA were observed for midlactation cows receiving a 14-d sustained release form of ST (Bauman et al., 1988). Elevated NEFA concentrations observed in the present experiment may indicate mobilization of body fat stores to provide energy for increased milk production when changes in feed intake fails to adequately match increased demands for milk production.

There were no main effects of ST on PUN (Table 3 ). Somatotropin increases muscle accretion through reduced protein turnover (Etherton and Bauman, 1998). A decrease in amino acid degradation can be reflected in lower PUN levels (Morris, 1992). In lactating cows, ST lowers urinary nitrogen excretion $(\mathrm{g} / \mathrm{d})$ and increases milk protein nitrogen $(\mathrm{g} / \mathrm{d})$ (Sechen and Bauman, 1989). Concentration of PUN is also decreased in primiparous cows receiving ST after six 14-d injection cycles (Cisse et al., 1991). Daily administration of ST in steers decreased PUN levels and increased protein accretion (Eisemann et al., 1989); however, a decrease in PUN has not been observed in all studies (Roeder, 1994).

Administration of ST increased $(P<0.05)$ plasma glucagon, during the third injection cycle (Table 3). Although numerically elevated during injection cycle 2 , the concentrations of insulin were not different $(P=$ $0.14)$ for cows given ST compared with controls. Likewise the molar ratio of insulin:glucagon was not altered by ST. Previous data indicate that plasma glucagon is increased in response to ST in lactating dairy cows (De Boer et al., 1991).

\section{mRNA Abundance}

Administration of ST elevated $(P=0.12)$ hepatic PEPCK mRNA abundance (Figure 1, Table 4) when data for injection cycle 2 and 3 are combined. However, administration of ST was more effective during the third injection cycle (time $\times$ treatment; $P<0.05$ ). Increased PEPCK mRNA reflects the effects of ST, as expression of PEPCK mRNA did not differ between the second and third injection cycles for cows given saline injections. 


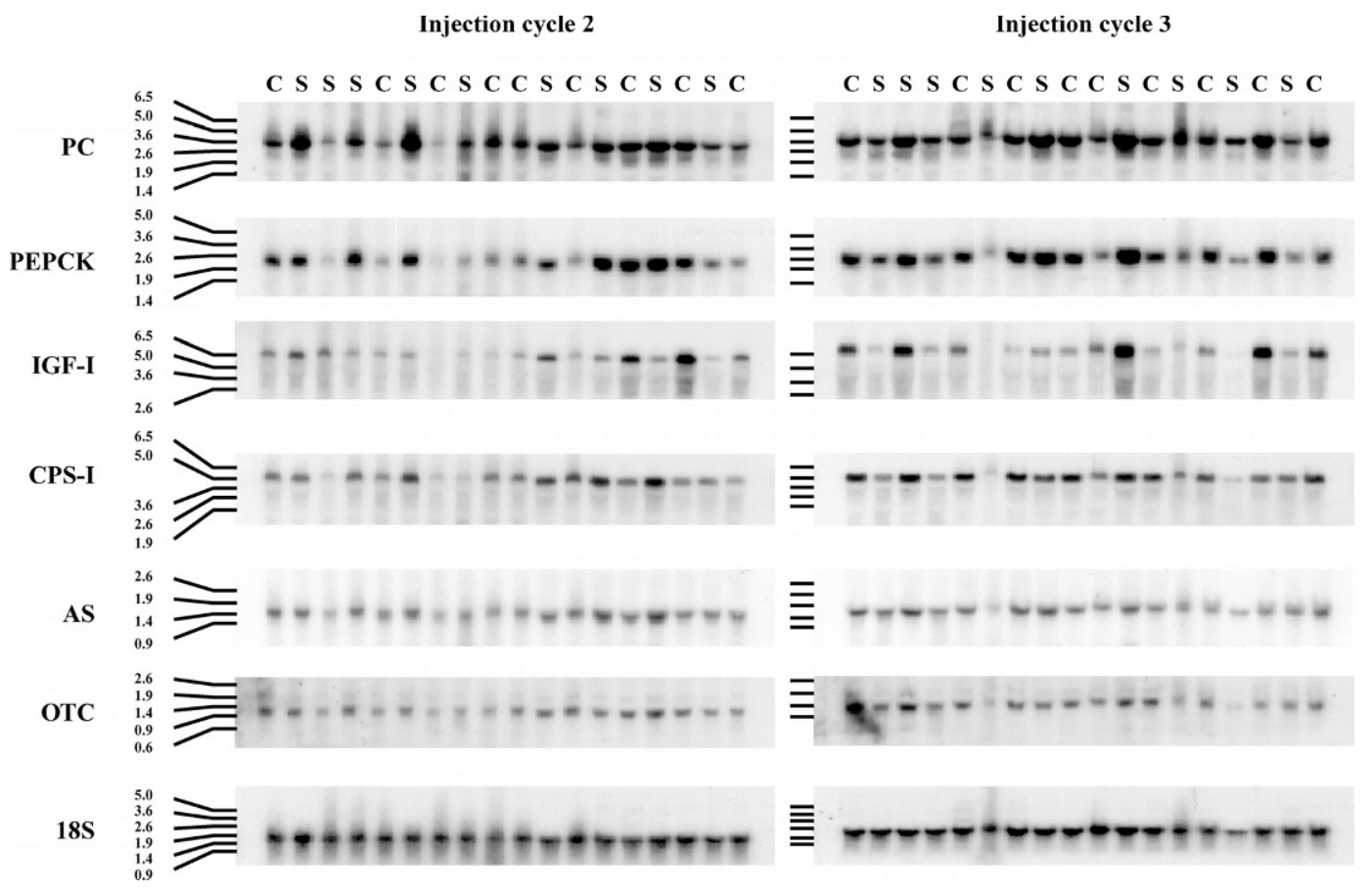

Figure 1. Northern blot analysis of hepatic pyruvate carboxylase (PC), phosphoenolpyruvate carboxykinase (PEPCK), IGF-I, arginpsiccunate synthetase (AS), carbamylphosphate synthetase-1 (CPS-I), and ornithine transcarbamylase (OTC) mRNA in lactating cows given bovine somatotropin (S) or saline (C). Cows were injected with recombinant somatotropin (ST) as Posilac (Monsanto, St Louis, MO) or saline on d 1,14 , and 28 of the experiment. Liver biopsy samples were obtained for mRNA analysis on d 21 (injection cycle 2) and 35 (injection cycle 3 ). Each lane contains $20 \mu \mathrm{g}$ of total RNA. The expression of $18 \mathrm{~S}$ rRNA within each lane was used to account for differences in sample loading and transfer.

An increase in PEPCK activity may represent one of the changes in gluconeogenesis in order to meet the requirements for increased milk production with ST.
The rate of conversion of $1{ }^{14} \mathrm{C}$ propionate to glucose was increased by twofold in liver from cows given ST, while the rate of conversion of $\left.1-{ }^{14} \mathrm{C}\right]$ propionate to the

Table 4. Effects of somatotropin (ST) on expression of pyruvate carboxylase (PC), phosphoenolpyruvate carboxykinase (PEPCK), IGF-I, GHR1A, carbamylphosphate synthetase I (CPS-I), and mRNA in liver of cows given ST Posilac (Monsanto, St. Louis, MO) or saline injections on d 1, 14, and 28 of the experiment and liver biopsy samples were obtained on d 21 and 35. Data are LS means of mRNA abundance (arbitrary units) and standard errors for main effects (treatment cycles 2 and 3 combined) unless noted otherwise.

\begin{tabular}{|c|c|c|c|c|c|}
\hline & \multicolumn{2}{|c|}{$\mathrm{ST}$} & \multicolumn{2}{|c|}{ Control } & \multirow[b]{2}{*}{$P$ value $^{1}$} \\
\hline & Mean & $\mathrm{SE}$ & Mean & $\mathrm{SE}$ & \\
\hline $\mathrm{PC}$ & 0.86 & 0.64 & 0.81 & 0.64 & 0.59 \\
\hline \multicolumn{6}{|l|}{ PEPCK $^{\mathrm{c}}$} \\
\hline Cycle 2 & 0.57 & 0.10 & 0.51 & 0.10 & 0.67 \\
\hline Cycle 3 & $0.74^{*}$ & 0.06 & 0.56 & 0.53 & $<0.05$ \\
\hline Overall & 0.66 & 0.05 & 0.53 & 0.05 & 0.12 \\
\hline GHRIA $^{\mathrm{b}}$ & 0.64 & 0.05 & 0.61 & 0.05 & 0.75 \\
\hline IGF-I ${ }^{\mathrm{a}}$ & $0.38^{*}$ & 0.07 & 0.15 & 0.07 & $<0.05$ \\
\hline CPS-I ${ }^{b}$ & 0.38 & 0.04 & 0.41 & 0.04 & 0.61 \\
\hline AS & 0.34 & 0.02 & 0.35 & 0.02 & 0.78 \\
\hline OTC & 0.23 & 0.03 & 0.28 & 0.03 & 0.41 \\
\hline
\end{tabular}

Treatment effect $(P<0.05)$.

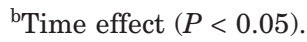

${ }^{\mathrm{c}}$ Treatment $\times$ time effect $(P<0.05)$.

${ }^{1} P$ value associated with treatment effect.

$*$ Mean for ST within a row differs from control $P<0.05$. 

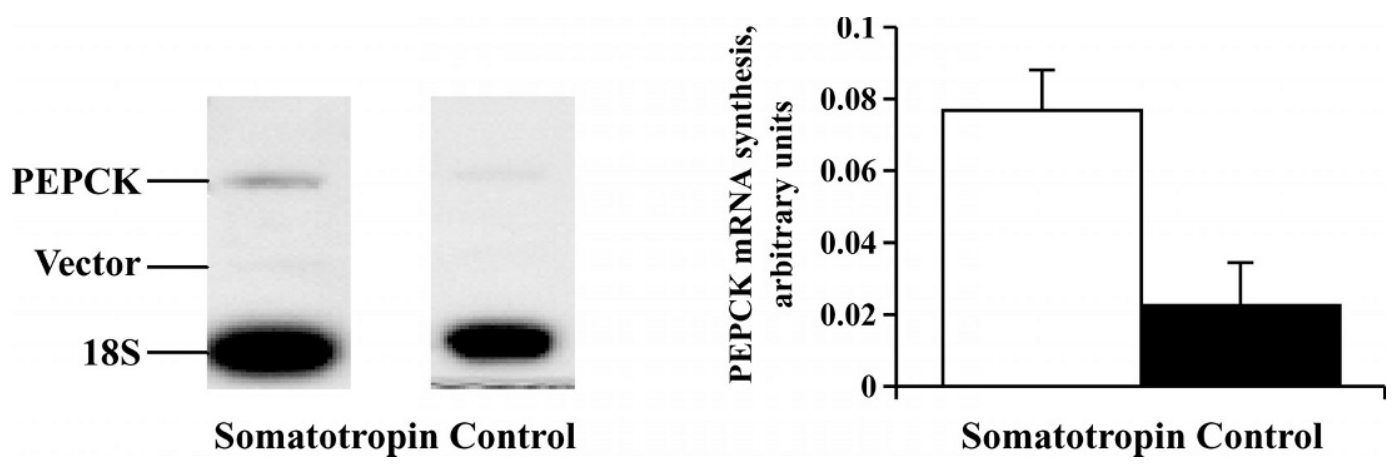

Figure 2. Effect of somatotropin on rate of transcription of phosphoenolpyruvate carboxykinase (PEPCK). Cows were injected with recombinant somatotropin (ST) as Posilac (Monsanto, St Louis, MO) or saline on d 1, 14, and 28 of the experiment. Liver biopsy samples were obtained for rate of transcription analysis on d 35. Nuclei were isolated from liver homogenates and subjected to run-on transcription assay. The reaction product was hybridized with target DNA immobilized on Genescreen (NEN Life Science Products, Boston, MA) membrane and the resulting membranes were quantified by densitometric scanning. Data was normalized using the abundance of $18 \mathrm{~S}$ transcribed. Representative membranes for ST and control (left panel) and densitometric analysis using nuclei from 3 separate cows (right panel) obtained during the third injection cycle are represented. Rate of transcription differs $(P<0.10)$ for control compared with ST.

sum of succinate, malate, and oxaloacetate was unchanged (Knapp et al., 1992). These data demonstrate that ST increases the flux of propionate carbon though PEPCK, and the subsequent reactions in gluconeogenesis. Several studies have shown that the increase in milk production with ST precedes a matching increase in feed intake (Bauman and Eppard, 1985; Peel and Sandles, 1985). Recombinant ST increased the rate of gluconeogenesis in support of lactation (Knapp et al., 1992). Glucose production from propionate was 2.3 -fold greater, while conversion of lactate and amino acids to glucose was unaffected by ST (Pocius and Herbein, 1986; Knapp et al., 1992) and suggests a repartitioning of propionate carbon towards glucose synthesis. Liver samples taken from 4 cows on 7 of initial administration of ST showed no detectable changes in the expression of PEPCK mRNA (Pershing et al., 2002). It is important to note that in the present study the scheduling of liver samples was designed to coincide with increased milk production that is observed during the second and later injection cycles of somatotropin (Bauman et al., 1989). Furthermore, the number of cows used in study reported previously (Pershing et al., 2002) may limit detection of differences due to somatotropin. Thus, increased expression of PEPCK mRNA in the present experiment is consistent with increased glucose formation from propionate during ST administration.

Transgenic rats expressing bovine growth hormone develop hyperinsulinemia and are refractory to the effects of insulin on peripheral tissues and liver (Valera et al., 1993). Chronic treatment with ST increases glucose and insulin concentrations in cattle (Eisemann et al., 1986; Sechen et al., 1990) and pigs (Chung el al., 1985). In addition, the rate of decline in plasma glucose during insulin challenge is also reduced with ST (Sechen et al., 1990). Furthermore, it is well documented that ST has direct actions to stimulate growth but has indirect antagonistic affects on insulin action. (Etherton et al., 1995). Thus, changes in expression of PEPCK mRNA abundance could reflect reduced hepatic sensitivity to insulin action.

There was tendency $(P=0.09)$ for an increase of in vitro elongation of PEPCK mRNA during administration of ST (Figure 2), a measure of the rate of transcription of the PEPCK gene. These data suggest changes in the transcription rate of the PEPCK gene in response to ST. Previous work demonstrated that ST did not affect PEPCK transcription rate in growing rats injected daily with ST (Donkin et al., 1996), and endogenous PEPCK expression was not altered in transgenic mice expressing the bovine ST gene (McGrane et al., 1990). The reasons for differences in ST effects on PEPCK expression and transcription between species are not obvious. A portion of the response to ST may be a consequence of differences in basal insulin sensitivity due either to species or physiological state (lactating vs. nonlactating). Ruminants are notoriously insulin insensitive (Brockman et al., 1990), and there is decreased insulin responsiveness during lactation (Sano et al., 1993). A lack of insulin responsiveness combined with increased rates of glucose entry in lactating cows given somatotropin when coupled with changes in transcription rate of PEPCK would suggest direct actions of ST on the PEPCK gene. Alternatively, an increase in the rate of transcription of the PEPCK gene and mRNA abundance may be secondary to coordinated changes in hormones, growth factors, and intermediary metabolites that accompanies an increase in milk production in response to ST administration. 
Expression of PC mRNA was not changed with ST (Figure 1, Table 4). Lactate, pyruvate, and alanine carbons are metabolized to oxaloacetate through PC. The rates of conversion for propionate and lactate to glucose are increased by ST, but there are no effects of ST on gluconeogenesis from amino acids (Knapp et al., 1992). This is not surprising given that increased protein synthesis and decreased protein turnover that occurs during administration of exogenous ST. Diversion of amino acids and supply of substrates for gluconeogenesis may increase flux of lactate to glucose despite lack of differences in PC activity. The lack of change in PC mRNA in the present experiment suggests a lack of change in capacity for flux through PC, as suggested previously (Knapp et al., 1992). Transition dairy cows have increased PC mRNA and activity at calving (Greenfield et al., 2000). Other work demonstrates that ST concentrations in blood are highest at calving (Ingalls et al., 1973). Therefore, the lack of effect of ST on PC suggests that any changes in PC mRNA at calving are not likely to be mediated by ST.

Expression of growth hormone receptor (GHR) mRNA was not different between ST or control cows (Figure 1, Table 4). Analysis by RPA for bGHR 1A transcript demonstrated a lack of difference in expression of bGHR 1A mRNA between ST and control cows. An increase in GHR mRNA has been observed during late lactation, but not midlactation, in cows given ST (Newbold et al., 1997; Kobayashi et al., 1999). Continuous infusion of ST does not alter GHR mRNA levels in liver of hypophysectomized rats (Maiter et al., 1992). Thus, increased PEPCK mRNA in the present experiment is not due to changes in GHR mRNA expression. Likewise, the lack of effect of ST on PC mRNA is not due to a lower receptor expression.

Hepatic expression of the 7.5-kb transcript of insulinlike growth factor-I (IGF-I) mRNA was increased $(P<$ 0.05 ) in response to ST (Figure 1, Table 4). Changes in IGF-I mRNA with ST were numerically greatest during the second injection cycle $(P<0.05)$ but also evident during the third injection cycle. Serum IGF-I responds more to ST when the protein and energy needs of cows are met (Vicini et al, 1991; McGuire et al. 1992). Elevated IGF-I mRNA with ST in the present experiment coupled with increased milk production is part of the anticipated response to ST. Based on these observations, an increase in PEPCK with ST is a component of the physiological adaptation to support elevated milk production with ST.

Abundance for CPS-I, ASS, and OTC mRNA (Figure 1, Table 4) determined by Northern blot analysis indicates a lack of effect of ST on expression of these enzymes. Ureagenesis is the final metabolic pathway of nitrogen disposal and is regulated by several factors including amino acids and hormones (Wolthers et al., 1997). The activities of the urea cycle enzymes are greatest during starvation or when protein is abundantly consumed (Morris, 1992). Growth hormone decreased CPS-I, AS, and OTC mRNA in rats and decreased urea $\mathrm{N}$ excretion, basal blood amino acid nitrogen, and the capacity of urea synthesis (Grofte et al., 1998). Administration of growth hormone, IGF-I, or a combination of these prevents the steroid-induced hepatic nitrogen clearance in man and rat (Wolthers et al., 1997; Grofte et al., 2001). Somatotropin does not affect the activities of aspartate aminotransferase, malate dehydrogenase, and lactate dehydrogenase, whereas alanine aminotransferase activity is increased (Knapp et al., 1992). The lack of change in expression of urea cycle enzymes mRNA with ST implies that any changes in urea synthesis as a consequence of altered amino acid metabolism may be insignificant in comparison to $\mathrm{N}$ from other sources, namely rumen metabolism. The present data would suggest that urea cycle capacity is not altered with ST.

The present data indicate that an increase in PEPCK mRNA abundance with administration of ST is one of the physiological adaptations necessary to modulate gluconeogenesis, and repartition nutrients toward milk synthesis. The lack of changes in expression of PC mRNA during ST administration indicates a lack of ST action to control lactate metabolism to glucose or at least a lack of regulation at the level of PC mRNA expression. Increased PEPCK mRNA abundance during ST administration in lactating dairy cows is a consequence of increased transcription of the PEPCK gene. The mechanism of ST action in this regard is not revealed through these studies but may involve direct effects of ST on liver, modulation of the actions of other hormones and metabolites, or both.

\section{REFERENCES}

Agca, C., R. B. Greenfield, J. R. Hartwell, and S. S. Donkin. 2002. Cloning and characterization of bovine cytosolic and mitochondrial PEPCK during transition to lactation. Physiol. Genomics 11:53-63.

Bauman, D. E. 1992. Bovine somatotropin: Review of an emerging animal technology. J. Dairy Sci. 75:3432-3451.

Bauman, D. E., C. J. Peel, W. D. Steinhour, P. J. Reynolds, H. F. Tyrell, A. C. G. Brown, and G. L. Haaland. 1988. Effect of bovine somatotropin on metabolism of lactating dairy cows: Influence on rates of irreversible loss and oxidation of glucose and nonesterified fatty acids. J. Nutr. 118:1031-1040.

Bauman, D. E., D. L. Hard, B. A. Crooker, M. S. Partridge, K. Garrick, L. D. Sandles, E. N. Hollis, S. E. Franson, G. F. Hartnell, and R. L. Hintz. 1989. Long-term evaluation of a prolonged-release formulation of n-methionyl bovine somatotropin in lactating dairy cows. J. Dairy Sci. 72:642-651.

Bauman, D. E., and P. J. Eppard. 1985. Responses of high-producing dairy cows to long-term treatment with pituitary somatotropin and recombinant somatotropin. J. Dairy Sci. 68:1352-1362. 
Bauman, D. E., and R. G. Vernon. 1993. Effects of exogenous bovine somatotropin on lactation. Annu. Rev. Nutr. 13:437-461.

Boisclair, Y. R., D. E. Bauman, A. W. Bell, F. R. Dunshea, and M. Harkins. 1994. Nutrient utilization and protein turnover in the hindlimb of cattle treated with bovine somatotropin. J. Nutr. 124:664-673.

Breier, B. H., and P. D. Gluckman. 1991. The regulation of postnatal growth: Nutritional influences on endocrine pathways and function of the somatotrophic axis. Livest. Prod. Sci. 27:77-94.

Brockman, R. P. 1990. Effect of insulin on the utilization of propionate in gluconeogenesis in sheep. Br. J. Nutr. 64:95-101.

Carroll, J. J., N. Smith, and A. L. Babson. 1970. A colorimetric serum glucose determination using hexokinase and glucose-6-phosphate dehydrogenase. Biochem. Med. 4:171-180.

Carter-Su, C., J. Schwarts, and L. S. Smit. 1996. Molecular mechanism of growth hormone action. Annu. Rev. Physiol. 58:187-207.

Chomczynski, P. N., and N. Sacchi. 1987. Single-step method of RNA isolation by acid guanidinium thiocyanate-phenol-chloroform extraction. Anal. Biochem. 162:156-167.

Chung, C. S., T. D. Etherton, and J. P. Wiggins. 1985. Stimulation of swine growth by porcine growth hormone. J. Anim. Sci. 60:118-130.

Cisse, M., Y. Chilliard, V. Coxam, M. J. Davicco, and B. Remond. 1991. Slow release somatotropin in dairy heifers and cows fed two levels of energy concentrate: Plasma hormones and metabolites. J. Dairy Sci. 74:1382-1394.

de Boer, G., P. H. Robinson, and J. J. Kennelly. 1991. Hormonal responses to bovine somatotropin and dietary protein in early lactation dairy cows. J Dairy Sci. 74:2623-2632.

Donkin, S. S., and L. E. Armentano. 1995. Insulin and glucagon regulation of gluconeogenesis in preruminating and ruminating bovine. J. Anim. Sci. 73:546-551.

Donkin, S. S., A. D. McNall, B. S. Swencki, J. L. Peters, and T. D. Etherton. 1996. The growth hormone-dependent decrease in hepatic fatty acid synthase mRNA is the result of a decrease in gene transcription. J. Endocrinol. 16:151-158.

Eisemann, J. H., A. C. Hammond, D. E. Bauman, P. J. Reynolds, S. N. McCutcheon, H. F. Tyrrell, and G. L. Haaland. 1986. Effect of bovine growth hormone administration on metabolism of growing Hereford heifers: Protein and lipid metabolism and plasma concentrations of metabolites and hormones. J. Nutr. 116:2504-2515.

Eisemann, J. H., A. C. Hammond, T. S. Rumsey, and D. E. Bauman. 1989. Nitrogen and protein metabolism and metabolites in plasma and urine of beef steers treated with somatotropin. J. Anim. Sci. 67:105-115.

Eppard, P. J., D. E. Bauman, and S. N. McCutcheon. 1985. Effect of dose of bovine growth hormone on lactation of dairy cows. J. Dairy Sci. 68:1109-1115.

Etherton, T. D., and D. E. Bauman. 1998. Biology of somatotropin in growth and lactation of domestic animals. Physiol. Rev. 78:745-761.

Etherton, T. D., S. S. Donkin, and D. E. Bauman. 1995. Mechanisms by which porcine somatotropin (pST) decreases adipose tissue growth in growing pigs. Pages 53-69 in The Biology of Fat in Meat Animals: Current Advances. S. B. Smith and D. R. Smith, eds.American Society of Animal Science, Champaign, IL.

Fei, H., and T. A. Drake 1993. A rapid nuclear runoff transcription assay. Biotechniques 15:838.

Gonipath, R., and T. D. Etherton. 1989. Effects of porcine growth hormone on glucose metabolism of pigs: I. Acute and chronic effects on plasma glucose and insulin status. J. Anim. Sci. 67:682-688.

Greenfield, R. B., M. J. Cecava, and S. S. Donkin. 2000. Changes in mRNA expression for gluconeogenic enzymes in liver of dairy cattle during the transition to lactation. J. Dairy Sci. 84:12281236.

Grofte, T., D. S. Jensen, H. Gronbaek, T. Wolthers, S. A. Jensen, N. Tygstrup, and H. Vilstrup. 1998. Effects of growth hormone on steroid-induced increase in ability of urea synthesis and urea enzyme mRNA levels. Am. J. Physiol. 275:E79-E86.

Grofte, T., D. S. Jensen, J. Greisen, N. Tygstrup, and H. Vilstrup. 2001. Growth hormone and insulin-like growth factor-I counter- acts established steroid catabolism in rats by effects of hepatic animo-N degradation. J. Hepatol. 35:700-706.

Hartnell, G. F., S. E. Franson, D. E. Bauman, H. H. Head, J. T. Huber, R. C. Lamb, K. S. Madsen, W. J. Cole, and R. L. Hintz. 1991. Evaluation of sometribove in a prolonged-release system in lactating dairy cows-production responses. J Dairy Sci. 74:2645-2663.

Herrington, J., L. S. Smit, J. Schwartz, and C. Carter-Su. 2000. The role of STAT proteins in growth hormone signaling. Oncogene 19:2585-2597.

Ingalls, W. G., E. M. Convey, and H. D. Hafs. 1973. Bovine serum $\mathrm{LH}, \mathrm{GH}$, and prolactin during late pregnancy, parturition and early lactation. Proc. Soc. Exp. Biol. Med. 143:161-164.

Johnson, M. M., and J. P. Peters. 1993. An improved method to quantify nonesterified fatty acids in bovine plasma. J. Anim. Sci.71:753-756.

Knapp, J. R., J. C. Freetly, B. L. Reis, C. C. Calvert, and R. L. Baldwin. 1992. Effects of somatotropin and substrates on patterns of liver metabolism in lactating dairy cattle. J. Dairy Sci. 75:1025-1035.

Kobayashi, Y., C. K. Boyd, C. J. Bracken, W. R. Lamberson, D. H. Keisler, and M. C. Lucy. 1999. Reduced growth hormone receptor (GHR) messenger ribonucleic acid in liver of periparturient cattle is caused by a specific down-regulation of GHR 1A that is associated with decreased insulin-like growth factor I. Endocrinology 140:3947-3954.

Maiter D., J. L. Walker, E. Adam, B. Moatsstaats, N. Mulumba, J. M. Ketelslegers, and L. E. Underwood. 1992. Differential regulation by growth hormone (GH) of insulin-like growth factor I and $\mathrm{GH}$ receptor/binding protein gene expression in rat liver. Endocrinology 130:3257-3264.

McDowell, G. H., J. M. Gooden, D. Leenanuruksa, M. Jois, and A. W. English. 1987. Effects of exogenous growth hormone on milk production and nutrient uptake by muscle and mammary tissues of dairy cows in mid-latation. Aust. J. Biol. Sci. 40:295-306.

McGrane, M. M., J. S. Yun, A. F. Moorman, W. H. Lamers, G. K. Hendrick, B. M. Arafah, E. A. Park, T. E. Wagner, and R. W. Hanson. 1990. Metabolic effects of developmental, tissue-, and cell-specific expression of a chimeric phosphoenolpyruvate carboxykinase (GTP)/bovine growth hormone gene in transgenic mice. J. Biol Chem. 265:22371-22379.

McGuire, M. A., J. L. Vicini, D. E. Bauman, and J. J. Veenhuizen. 1992. Insulin-like growth factors and binding proteins in ruminants and their nutritional regulation. J. Anim. Sci. 70:29012910 .

Morris, S. M., Jr. 1992. Regulation of enzymes of urea and arginine synthesis. Annu. Rev. Nutr. 12:81-101.

Newbold, J. A., R. B. Heap, C. G. Prosser, R. H. Phipps, F. Adriaens, and D. L. Hard. 1997. The effect of bovine somatotropin and diet on somatotropin binding sites in hepatic tissue of lactating dairy cows. J. Dairy Sci. 80:1085-1091.

Nielsen, M. O., T. G. Madsen, and A. M. Hedeboe. 2001. Regulation of mammary glucose uptake in goats: Role of mammary gland supply, insulin, IFG-I, and synthetic capacity. J. Dairy Res. 68:337-349.

National Research Council. 2001. Nutrient Requirements of Dairy Cattle. 7th Revised Edition. National Academy Press, Washington, DC.

Peel, C. J., T. J. Fronk, D. E. Bauman, and R. C. Gorewit. 1983. Effect of exogenous growth hormone in early and late lactation on lactational performance of dairy cows. J. Dairy Sci. 66:776-782.

Peel, C. J., and L. D. Sandles. 1985. The effect of long-term administration of bovine growth hormone on the lactational performance of identical-twin dairy cows. Anim. Prod. 41:135-142.

Pershing, R. A., S. D. Moore, A. C. Dinges, W. W. Thatcher, and L Badinga. 2002. Short communication: Hepatic gene expression for gluconeogenic enzymes in lactating dairy cows treated with bovine somatotropin. J. Dairy Sci. 85:504-506.

Pilkis, S. J., and D. K. Granner. 1992. Molecular physiology of the regulation of hepatic gluconeogenesis and glycolysis. Annu. Rev. Physiol. 54:885-909. 
Pocius, P. A., and J. H. Herbein. 1986. Effects of in vivo administration of growth hormone on milk production and in vitro hepatic metabolism in dairy cattle. J. Dairy Sci. 69:713-720.

Roeder, R. A., M. J. Garber, B. S. Dalke, T. R. Kasser, J. Veenhuizen, and G. T. Schelling. 1994. Effects of recombinant bovine somatotropin implants on serum concentrations of somatotropin, insulinlike growth factor-I and blood urea nitrogen in steers. Growth Regul. 4:101-107.

Sano, H., S. Narahara, T. Kondo, A. Takahashi, and Y. Terashima. 1993. Insulin responsiveness to glucose and tissue responsiveness to insulin during lactation in dairy cows. Domest. Anim. Endocrinol. 10:191-197.

Schibler, U., O. Hagenbuchle, P. K. Wellauer, and A. C. Pittet. 1983. Two promoters of different strengths control the transcription of the mouse alpha-amylase gene Amy-1a in the parotid gland and the liver. Cell 33:501-508.

Sechen, S. J., and D. E. Bauman. 1989. Effect of somatotropin on kinetics of nonesterified fatty acids and partition of energy, carbon, and nitrogen in lactation dairy cows. J. Dairy Sci. 72:59-67.

Sechen, S. J., F. R. Dunshea, and D. E. Bauman. 1990. Somatotropin in lactation cows: Effect on response to epinephrine and insulin. Am. J. Physiol. 258:E582-E588.
Stanisiewski, E. P., L. F. Krabill, and J. W. Lauderdale. 1992. Milk yield, health and reproduction of dairy cows given somatotropin (somavubove) beginning early postpartum. J. Dairy Sci. 75:2149-2164.

Tsang, S. S., X. Yin, C. Guzzo-Arkuran, V. S. Jones, and A. J. Davison. 1993. Loss of resolution in gel electrophoresis of RNA: A problem associated with the presence of formaldehyde gradients. Biotechnology 14:380-391.

Valera, A., J. E. Rodriguez-Gil, J. S. Yun, M. M. McGrane, R. W. Hanson, and F. Bosch. 1993. Glucose metabolism in transgenic mice containing a chimeric P-enolpyruvate carboxykinase/bovine growth hormone gene. FASEB J. 7:791-800.

Vicini J. L., F. C. Buonomo, J. J. Veenhuizen, M. A. Miller, D.R. Clemmons, and R. J. Collier. 1991. Nutrient balance and stage of lactation affect responses of insulin, insulin-like growth factors I and II, and insulin-like growth factor-binding protein 2 to somatotropin administration in dairy cows. J. Nutr. 121:1656-1664.

Wolthers, T., T. Grofte, J. O. L. Jorgensen, and H. Vilstrup. 1997. Growth hormone prevents prednisolone-induced increase in functional hepatic nitrogen clearance in normal man. J. Hepatol. 27:789-795. 